\title{
The Holocaust, medicine and becoming a physician: the crucial role of education
}

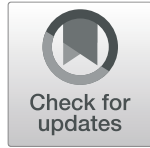

Shmuel P. Reis ${ }^{{ }^{*}} \mathbb{D}$, Hedy S. Wald ${ }^{2}$ and Paul Weindling ${ }^{3}$

\begin{abstract}
Learning about the abandonment of moral principles of healthcare professionals and scientists, their societies and academic institutions, to a murderous ideology yields fundamental concerns and global implications for present and future healthcare professionals' education and practice. Medicine's worst-case scenario raises deeply disturbing yet essential questions in the here and now: Could the Holocaust, one of the greatest evils ever perpetrated on humankind, have occurred without the complicity of physicians, their societies, and the scientific profession community? How did healers become killers? Can it happen again?

We reflect here on those queries through the lens of the Second International Scholars Workshop on Medicine during the Holocaust and Beyond held in the Galilee, Israel on May 7-11, 2017 and derive contemporary global lessons for the healthcare professions. Following a brief historical background, implications of the history of medicine in the Holocaust are drawn including 1) awareness that the combination of hierarchy, obedience, and power constitutes a risk factor for abuse of power in medicine and 2) learning and teaching about medicine in the Holocaust and beyond is a powerful platform for supporting professional identity formation. As such, this history ideally can help "equip" learners with a moral compass for navigating the future of medical practice and inherent ethical challenges such as prejudice, assisted reproduction, resource allocation, obtaining valid informed consent, end of life care, and challenges of genomics and technology expansion. Curriculum modules are available and studies on impact on students' attitudes and behavior are emerging.

The conference culminated with the launch of the Galilee Declaration, composed and signed by an international, interprofessional community of historians, healthcare professions educators, and ethicists. The Declaration included herein (http://english.wgalil.ac.il/category/Declaration) calls for curricula on history of healthcare professions in the Holocaust and its implications to be included in all healthcare professions education.
\end{abstract}

Keywords: Holocaust and medicine, Medical education, Professional identity formation, Bioethics

The Holocaust. A zenith of profound evil afflicted by human beings upon their fellow humans under National Socialism (1940-45) [1, 2]. "Never again" is a resounding promise for a civilized society, and "never again" for the medical profession as well. While many professions swept by Nazi ideology went overboard to please the Führer, physicians and other healthcare professionals were among the most avid [3, 4]. Forty-five percent of German physicians, for example, joined the Nazi party (many of those even before Hitler's rise to power) compared to $7 \%$ of teachers in Germany [4]. Learning about and reflecting upon the

\footnotetext{
* Correspondence: shmuelre@ekmd.huji.ac.il

${ }^{1}$ Center for Medical Education, Hadassah/Hebrew University Faculty of Medicine, P.O.B 12272, 9112102 Jerusalem, Israel

Full list of author information is available at the end of the article
}

abandonment of moral principles of individual healthcare professionals and scientists and more broadly, their societies and academic institutions, to a murderous ideology yields fundamental concerns and global implications for present and future healthcare professionals' education and practice [5-7]. Medicine's worst-case scenario [8] raises deeply disturbing yet essential questions in the here and now: Could the Holocaust, one of the greatest evils ever perpetrated on humankind, have occurred without the complicity of physicians, their societies, and the scientific profession community? How did healers become killers? Can it happen again? We reflect here on those queries through the lens of the Second International Scholars Workshop on Medicine during the Holocaust and Beyond held in the Galilee, Israel on May 7-11, 2017 and derive

(C) The Author(s). 2019 Open Access This article is distributed under the terms of the Creative Commons Attribution 4.0 International License (http://creativecommons.org/licenses/by/4.0/), which permits unrestricted use, distribution, and 
contemporary global lessons for the healthcare professions. This gathering of over 100 historians, physicians, nurses, medical and university educators, medical students, ethicists and more from 17 countries presenting on history, healthcare professions education, and bioethics addressed this dark chapter of history and contemplated its implications for current and future practitioners and researchers.

\section{Background}

Some historical background is presented here as context for this workshop: Five "programs" deliberately launched by the Nazis established the priority of the "health" of the State or "Volk" over the health of individuals and dehumanized those considered "unworthy of life." first, the Jewish medical presence was eliminated from Nazi Germany (1935-1939). A second program consisted of involuntary sterilization of disabled German citizens (Jews included) (1933-1939), followed by a third, "euthanasia" of (mostly) Germans and Austrians whose lives were deemed medically "unworthy of living," including the disabled and mentally ill (1939-1945). Fourth, horrific experiments on numerous persons ranging from mixed-race Afro-German children to Jews in Auschwitz were conducted throughout this period (1933-1945) [9] and fifth, medicalized genocide aimed to annihilate European Jewry and other "undesirables" (1941-1945), indeed from 1940 given that Jewish psychiatric patients were prioritized for killing with carbon monoxide gas. These programs were proposed, planned, organized, and implemented (contributed to for the fifth) by healthcare professionals and scientific institutions, implicating almost the entire scientific and medical enterprise of Germany and annexed Austria [6,7]. The sequence of events was gradual. The first two "programs" enacted prior to World War II rendered an estimated 350, 000 persons forcibly sterile and resulted in several thousand Jewish physicians being ousted from their jobs with many committing suicide or eventually perishing in the ghettoes and death camps. In this prelude to what was to follow, German and Austrian physicians and their institutions engaged in reporting, "legally" sanctioning, and executing these first two crimes. "The Holocaust started in the dark basements of German hospitals" [10].

Once the war began on September 1, 1939, Hitler permitted transitioning from sterilization to the T4 ("euthanasia") program where, once again, German and Austrian disabled individuals were gassed. While this program officially ceased in August, 1941 after public protest with the Catholic Bishop Galen taking a lead, medical teams continued to perform "wild euthanasia" on a decentralized basis similar to the "special care children's units" until late May, 1945. During 1941, the infrastructure, personnel and expertise of the T4 program were transferred east to serve the emerging "Final Solution" (plan to annihilate European Jewry officially launched in January 1942), by building the first three extermination camps on German-occupied Polish soil: Sobibor, Belzec, and Treblinka, as well as testing Zyklon gas for killing sick Poles and Russian prisoners in September 1941 in Auschwitz before large scale killing of Jews from 1942. It was also in Auschwitz where sick prisoners were routinely killed with lethal injections or sent to the gas chambers. Intermediary steps toward achieving the Holocaust included massive population transfers to ghettoes and labor camps fueled by medical advice on such actions "preventing epidemics" [11] and genocide by bullets in territories seized from the Soviet Union during the 1941-44 German invasion. In parallel, experimentation on ca 18,000 prisoners and patients, with medical and scientific establishments competing for generous research grants offered to support war related and racial research [12]. The pre-existing German Medical Ethics Guidelines of 1931 did not prevent such abuse and violation of human rights [13]. In the death camps, physicians conducted a disinformation charade intended to mislead with white coats and ambulances on the train ramps, followed by the infamous selection of immediately "diagnosing" the few who may be fit for work and sending the vast majority of deportees to gas chambers and crematoria. The image of the "angel of death" Josef Mengele MD, PhD looms large as the icon of medical presence selecting on the ramp of Auschwitz a select minority for forced labor and most for immediate killing by poison gas, as well as twins and persons with genetic growth defects for coerced experiments and extraction of soft tissue, body fluids and bones [4]. Mengele did not act alone. Research implicates numerous German and Austrian medical physicians and others in the scientific community as participating in this unprecedented breach of ethics and humanity [14].

Additional issues raised during the conference included the involvement of pharma in exploiting available slave labor and participating in unethical experiments, examples of the international medical community and its journals giving voice to, supporting, and publishing policies, ideology and "scientific" results of the Nazi medical and scientific communities, failures of compliance in many countries with ethical codes formulated in the aftermath of the Holocaust, and finally denial with transparency obstruction of the medical atrocities and their perpetrators in involved countries. Essential lessons for health professionals in all stages of the professional life cycle derive from studying history highlighting what may occur when ideology fuels evil distortion of medicine and science. The conference confronted the history of the often-central role of Nazi healthcare professionals in atrocities including exclusion of persons categorized as racially "sub humans" from the realm of ethical consideration, human beings labeled as unworthy of living [15], starvation and other forms of "legally" administered torture, and barbaric experiments conducted in the ruthless pursuit for "medical knowledge." 
Implications of the history of medicine in the Holocaust for medical ethics and education

Potential for abuse of power is inherent to medicine. Healthcare can involve the application of aggressive, potentially painful and distressing modalities, i.e. delivering bad news, surgery, resuscitation, distressing and often painful diagnostic and therapeutic procedures. Physicians hold the power to announce and certify death, assist in reproductive technologies, admit against a patient's will, and supply a host of certificates and reports which profoundly affect patients' lives and welfare. Medicine is a hierarchical profession, with senior clinicians issuing orders to be carried out by junior ones, and where physicians often direct or command allied health personnel [16]. While these features of medicine are applied with the noble goal of healing and administering best practices within humanistic care, the combination of elements of hierarchy, obedience, and power constitutes a risk factor for abuse of power [2, 16]. What prevents potentialities for abuse of power in medicine from becoming reality?

Such existential deliberations were integrated at the conference within medical education imperatives, i.e. considering how the history of medicine under the Third Reich informs and shapes contemporary clinical ethics, human subject experimentation checks and balances, and required ethics committees, ethics consults, and institutional review boards (IRBs). An ethics code or instruction cannot suffice - "medical ethics" in Nazi-era medical school curricula existed, yet included "unequal worth of human beings, authoritative role of the physician, and priority of public health over individual patient care" $[17,18]$ Nazi physicians, idealistic in a perverse way, earnestly believed what they were doing was right [19]. While no physician was present in the Wannsee meeting that formally confirmed the plan for genocide of the Jewish people, [20] programs 1-4 as described above could not have been realized without individual physicians and the medical and scientific communities playing a decisive role in the planning and implementation of such programs. As for program \#5, most horrific of all, the question of whether the Holocaust could have occurred without the contributions of the medical and scientific professions is haunting. Nearly 100 conference presentations included topics such as the medical/scientific community's involvement in medical atrocities and bioethics after the Holocaust as well as medical activity (including ethical dilemmas) in ghettos and camps, genocide conditions, treatment of survivors and their offspring, resilience and post-trauma [21].

Learning and teaching about medicine in the Holocaust and beyond is a powerful platform for supporting professional identity formation. As such, this history ideally can help "equip" learners with a moral compass for navigating the future of medical practice and inherent ethical challenges such as prejudice, assisted reproduction, resource allocation, obtaining valid informed consent, end of life care, and challenges of genomics and technology expansion [7]. In addition to its relevance within overt racism and prejudice, medicine in the Holocaust pedagogy is germane to increasing awareness of potential for implicit bias to shape healing relationships, albeit in subtle ways, and efforts to identify, reduce, and ideally eliminate this characteristic within healthcare professions practice [22, 23].

Fostering reflection on the history of the profession has the potential to broaden learners' perspectives, raise awareness, and promote empathy, compassion, and tolerance of the "other" [6, 24]. Medical student-authored publications have highlighted the contemporary relevance of Holocaust and Medicine curriculum for professional development $[25,26]$ as "hard truths are faced," i.e. "What exactly did Nazi physicians do; how are their actions a part of Western medicine's legacy [25]; and what can we do as a profession to prevent a repeat?"

Within this, there is increasing attention to the valuable contribution of the history of medicine within the medical humanities to medical education [27]. The inclusion of examples of altruism, deep humanity, and devotion to medicine as a calling while risking one's life and the life of one's family during the Holocaust can serve as inspiration [5-7]. Jewish prisoner healthcare professionals as well as "righteous of the nations' ones" cared for patients, taught junior learners, conducted research, and manifested resistance to evil even under brutal conditions and in mortal danger [2830]. The Warsaw Ghetto heroic Jewish healthcare system, its clandestine medical school, and the Hunger Study [31, 32] as well as Ludwik Fleck's typhus vaccine sabotage, and the White Rose student resistance group based in the Munich medical school are some specific exemplars [28-30].

Holocaust and Medicine curriculum modules are integrated into health professions curricula [6], with further examples included at http://www.medicineaftertheholocaust.org/category/curricula-syllabi/. Studies of curriculum impact on students' attitudes and behavior are emerging [33] including within a 3 year credit-earning elective curriculum for interprofessional students (including study excursions to Holocaust sites; students may participate in any/all of the years) at the Witten-Herdecke University Faculty of Health-Integrated Curriculum for Anthroposophic Medicine (ICURAM) in collaboration with the Ita Wegman Institute (https://ibam.uni-wh.de/ en/, http://www.wegmaninstitut.ch/).

The Scholars Workshop on Medicine during the Holocaust and Beyond culminated with the launch of the Galilee Declaration, composed and signed by an international, inter-professional community of historians, healthcare professions educators and ethicists (additional signatures invited.) The Declaration (included below) and accessed at: http://english.wgalil.ac.il/category/Declaration) calls for curriculum on history of healthcare 
professions in the Holocaust and its implications to be included in all healthcare professions education. The document emulates the 2000 Stockholm Declaration [34] that transformed general Holocaust education worldwide, with the intention of similar impact.

\section{Conclusions: what global lessons can we draw from this critical reflection?}

It is about the major ethical questions of our time: the soul of care, equity in healthcare, resource allocation, pharma ethical conduct, non-exploitation of the vulnerable, poor and marginalized, rights of the disabled, beginning and end of life issues... and more. It is about current and future health professionals being cognizant of the inherent danger of abuse of power in medicine and the need for "immunizing" ourselves for prevention. Challenges abound within the practice of healing, given reality of violence [35], stress, fatigue, burnout-inducing systems factors [36] and potential dilemmas of dual commitment (eg. physicians in uniform) [37]. It is about critical aspects of professionalism, professional identity formation, and prevention of abuse of power. These include desired professional competencies of conscience, empathy, compassion, reflection, and resilience (emotional and moral) in the individual health professional in conjunction with additional technical competencies. It is also about checks and balances, remembering and commemorating, learning and teaching within the shared humanity of individuals, institutions, societies, and nations.

May we carry Primo Levi's words as an everlasting reminder: "It can happen, and it can happen everywhere" [38].

\section{Abbreviation}

T4: The Nazi "euthanasia" program (1939-41) in which Germans \& Austrians whose lives were considered "unworthy of living" were gassed. T4 stands for the address of the office overseeing this program

\section{Acknowledgements}

None.

\section{The Galilee Declaration *}

The participants in the Galilee Second International Workshop on Medicine after the Holocaust pledge the following: We unequivocally support the universal principles of the 2000 Declaration of the Stockholm International Forum on the Holocaust, namely:

a. The Holocaust (Shoah) fundamentally challenged the foundations of civilization. The unprecedented character of the Holocaust will always hold universal meaning. b. The magnitude of the Holocaust, planned and carried out by the Nazis, must be forever seared in our collective memory. c. With humanity still scarred by genocide, ethnic cleansing, racism, anti-Semitism and xenophobia, the international community shares a solemn responsibility to fight those evils. Together we must uphold the terrible truth of the Holocaust against those who deny it. We must strengthen the moral commitment of our peoples, and the political commitment of our governments, to ensure that future generations can understand the causes of the Holocaust and reflect upon its consequences. $d$. We pledge to strengthen our efforts to promote education, remembrance and research about the Holocaust, both in countries that have already undertaken such initiatives and in those that choose to join this effort.

We unequivocally assert that a moral imperative compels all health professions to supplement the Stockholm Declaration as follows:
1. Professionals from science, medicine and other healthcare and social science fields played decisive roles in justifying, developing and carrying out some of the most appalling atrocities of the Third Reich, including the compulsory sterilization and medicalized murder of Germans, Austrians and other lives deemed unworthy of living; unethical, brutal experimentation on hospital patients and prisoners; and the unprecedented persecution, including mass murder and the Holocaust - the unique, partially-medicalized genocide of Jews and many others.

Health professionals were prominent among the Nazi perpetrators and their collaborators with these heinous crimes, which were ostensibly designed to improve the health of the German population. Most of them remained unrepentant long after the Nuremberg trials. Acknowledging these medical atrocities is a continuing responsibility for all health professionals, their societies, and institutions.

2. We acknowledge that the destructive potential of science focused solely on knowledge acquisition and population health without care for individual human beings peaked during the Third Reich with its extreme dehumanizing political conditions and profound moral failures of its health care and scientific establishments. These failures pose a major challenge to contemporary medicine, and they compel us to ensure that the lessons of the Holocaust are integrated into the identities of present and future physicians and other health professionals.

3. We share a commitment to encourage the study of the roles of health professionals in medical atrocities committed during the Nazi period, leading up to and including the Holocaust, and the many implications that this legacy holds for us for today. This study should also include the achievements in maintaining high professional and human standards by some physicians and other persons entrusted with health care during the Holocaust.

4. We share the general obligation of humanity to remember all the victims of medical atrocities during the Nazi period including the Holocaust and to honor all those who stood against it. We also share a special obligation to prevent the abuse of power in our healing professions. We therefore believe in recognizing the unique and critical roles played by health professionals, remembering those who were their victims, and honoring those who held true to their healers' oaths in extreme circumstances.

5. We share a commitment to shed light on the still obscured shadows of physicians and other health professionals, societies and institutions that perpetrated medical atrocities during the Nazi period. We will take all necessary steps to facilitate the opening of archives to ensure that all documents relevant to the role of medicine in the Holocaust are available to researchers.

We call on institutions of higher learning in all healthcare professions and allied fields to incorporate into their curricula courses and programs on medicine and the Holocaust and its implications for contemporary practice, research and healthcare policy, and to support each other in implementing this Declaration.

*emulating the Stockholm declaration.

\section{Authors' contributions}

All authors contributed to the manuscript planning and writing. All authors read and approved the final manuscript.

\section{Funding}

No financial support.

\section{Availability of data and materials \\ NA}

Ethics approval and consent to participate

NA

Consent for publication

NA 


\section{Competing interests}

The authors declare that they have no competing interests.

\section{Author details}

${ }^{1}$ Center for Medical Education, Hadassah/Hebrew University Faculty of Medicine, P.O.B 12272, 9112102 Jerusalem, Israel. ${ }^{2}$ Department of Family Medicine, Warren Alpert Medical School of Brown University, Providence, RL USA. ${ }^{3}$ Wellcome Trust Research Professor in the History of Medicine in the Department of History, Oxford Brookes University, Oxford, UK.

Received: 24 March 2019 Accepted: 11 June 2019

Published online: 27 June 2019

\section{References}

1. Bartov O. The Holocaust: origins, implementation, aftermath. 2nd ed. London: Routledge; 2015.

2. Waller JE. Becoming Evil: How Ordinary People Commit Genocide and Mass Murder. 2nd ed. New York: Oxford University Press; 2007.

3. Kater MH. Doctors under Hitler. Chapel Hill: The University of North Carolina Press; 1989.

4. Kater MH. Hitler's early doctors: Nazi physicians in pre-depression Germany. J Mod Hist. 1987:59(1):25-52

5. Reis S. Holocaust and medicine--a medical education agenda. Isr Med Assoc J. 2007:9(3):189-91.

6. Reis SP, Wald HS. Contemplating medicine during the third Reich: scaffolding professional identity formation for medical students. Acad Med. 2015;90(6):770-3.

7. Reis SP, Wald HS. Learning from the past: medicine and the Holocaust Lancet. 2009;374(9684):110-1.

8. Reis S, Maier M. WONCA Europe in Vienna 2012--what have we learned? Fam Pract. 2012:29(6):623-5.

9. Weindling P, Villiez AV, Loewenau A, Farron N. The victims of unethical human experiments and coerced research under national socialism. Endeavour. 2016;40(1):1-6 http://www.sciencedirect.com/science/article/pii/ S0160932715300235. Accessed 19 May 2019.

10. Fishkoff, S. (1996). "They called it mercy killing." Jerusalem Post, p.8.

11. Hilberg R. The destruction of the European Jews. Hebrew edition 2012, Yad Vashem. Vol 1 p198.

12. Weindling P. Victims and survivors of Nazi human experiments: science and suffering in the Holocaust. London: Bloomsbury; 2014.

13. Roelcke $V$. The use and abuse of medical research ethics: The German Richtlinien / guidelines for human subject research as an instrument for the protection of research subjects - and of medical science, ca. 1931-1961/64. In: Weindling P, editor. From Clinic to Concentration Camp: Reassessing Nazi Medical and Racial Research, 1933-1945. London: Routledge; 2017. p. 33-56.

14. Reis S. Reflections on the Nuremberg declaration of the German medical assembly. Isr Med Assoc J. 2012;14:532-4.

15. Samson, A. (2013). Karl Binding and Alfred Hoche Publish $<i>$ Die Freigabe der Vernichtung lebensunwerten Lebens</i>. Retrieved May 19, 2019 from http://eugenicsarchive.ca/discover/connections/52336abe5c2ec50000000048

16. Cassell EJ. Consent or obedience? Power and authority in medicine. N Engl J Med. 2005:352(4):328-30

17. Bruns F, Chelouche T. Lectures on inhumanity: teaching medical ethics in German medical schools under Nazism. Ann Intern Med. 2017:166(8):591-5.

18. Wald, HS. Confronting Medicine in the Holocaust and Beyond. https:// reflectivemeded.org/2017/06/29/confronting-medicine-in-the-holocaustbeyond/ Accessed 19 May 2019.

19. Wald HS, Rubenfeld S, Fins JJ. The Holocaust as End Stage Disease: Medical Education as a Moral Imperative. Hektoen International Spring 2016. http:// hekint.org/the-holocaust-as-end-stage-disease-medical-education-as-amoral-imperative/ Accessed 19 May 2019

20. Roseman M. The Villa, the Lake, the meeting: Wannsee and the final solution. London: Allen Lane; 2002

21. Medicine in the Holocaust and Beyond - Second International Scholars Workshop, Galilee, Israel. https:/wwww.wgalil.ac.il/ba/multidisciplinary/holocaust_studies program/holocaust_conferences/holocaust_medicine/ Accessed 19 May 2019

22. Lynch HF. Discrimination at the doctor's office. N Engl J Med. 2013;368(18): 1668-70.

23. Byrne A, Tanesini A. Instilling new habits: addressing implicit bias in healthcare professionals. Adv Health Sci Educ Theory Pract. 2015;20(5):1255-62.
24. Wald HS. Refining the definition of reflection for the being as well as the doing the work of a physician. Med Teacher. 2015:37(7):696-9.

25. Woznica, E. The Legacy of Nazi Physicians. Brown Magazine, Fall 2014. https://medicine.at.brown.edu/article/the-legacy-of-nazi-physicians/ / Accessed 19 May 192019.

26. Weiner SB. Holocaust and medicine: contemporary relevance for medical students. Amer Med Student Research J. 2018;5(1):154-6.

27. Greene JA, Jones DS. The shared goals and distinct strengths of the medical humanities. Can the sum of the parts be greater than the whole? Acad Med. 2017;92(12):1661-4

28. Roland CG. An underground medical school in the Warsaw ghetto, 1941-2. Med Hist. 1989;33(4):399-419.

29. Grzybowski A, Ciesielska M. Lesser known aspects of Ludwik Fleck's (18961961) heroic life during world war II. J Med Biogr. 2016;24(3):402-8.

30. White Rose. https://www.ushmm.org/wlc/en/article.php?Moduleld=10007188. Accessed May 19, 2019.

31. Offer M. White Coats Inside the Ghetto: Jewish Medicine in Poland During the Holocaust (Heb). Yad Vashem Publications 2015.

32. Offer M. The study of Jewish medicine during the Holocaust: its creation and preliminary steps. Korot. 2014:22:129-54.

33. Gonzalez-Lopez E, Rios-Cortes R. Medical students' opinions on some bioethical issues before and after a Holocaust and medicine course. IMAJ. 2019;21:298

34. https://archive.org/stream/DeclarationOnStockholm2000/ DeclarationOnStockholm2000_djvu.txt. Accessed 18 June 2019.

35. Phillips JM. Workplace violence against health Care Workers in the United States. N Engl J Med. 2016;374:1661-9.

36. Shanafelt TD, Noseworthy JH. Executive leadership and physician wellbeing: nine organizational strategies to promote engagement and reduce burnout. Mayo Clin Proc. 2017;92(1):129-46.

37. Howe EG. When, if ever, should military physicians violate a military order to give medical obligations higher priority? Mil Med. 2015;180(11):1118-9.

38. Levi, P. https://www.goodreads.com/quotes/264502-we-must-be-listened-toabove-and-beyond-our-personal\%20. Accessed 19 May 2019.

\section{Publisher's Note}

Springer Nature remains neutral with regard to jurisdictional claims in published maps and institutional affiliations.

Ready to submit your research? Choose BMC and benefit from:

- fast, convenient online submission

- thorough peer review by experienced researchers in your field

- rapid publication on acceptance

- support for research data, including large and complex data types

- gold Open Access which fosters wider collaboration and increased citations

- maximum visibility for your research: over $100 \mathrm{M}$ website views per year

At $\mathrm{BMC}$, research is always in progress.

Learn more biomedcentral.com/submissions 